\title{
SOME ASPECTS OF MULTIMEDIA TECHNOLOGY AS A MEANS OF IMPROVING THE QUALITY OF FOREIGN LANGUAGE TEACHING
}

\author{
Olga Kryuchkova ${ }^{4}$
}

\begin{abstract}
The article is focused on some of the issues encountered in using multimedia technologies in foreign languages teaching. The process of the advent of ICTs is particularly relevant in the period of rapid informatisation of society. The article presents a review of the findings of some of the Russian scholars engaged in the research on the application of multimedia technologies in foreign language teaching in a non-linguistic environment and covers the way multimedia technologies can be applied in the teaching of phonetics, grammar, and vocabulary. The focus is on one particular program, i.e. iSping.
\end{abstract}

Key words: multimedia technology, e-learning, foreign language, e-textbook, iSping

\section{Introduction}

Rapid informatisation of education is a distinctive feature of today's reality. Computer technologies are being actively developed and introduced into all fields of life, and education is no exception.

It is information and communication technologies that are the optimal means for self-development, individual education, and self-education; they are actively used to attract learners' interest in the educational process.

Recently, the issues of quality of language education have acquired a special urgency, which is explained by profound social, economic, and political changes, increasing scientific knowledge about the regularities of education in general and language education in particular, a change in the conceptual orientation of language education, its objectives, content, and education technology corresponding to the standard established by Federal state educational standards (Bartosh, Galskova, Koptelov \& Kharlamova, 2018, p. 71).

4. Post-graduate student, Moscow City Pedagogical University, Institute of Pedagogy and Psychology Education, Russia, e-mail: olja-kr4@mail.ru, ORCID: 0000-0002-4737-2982 


\section{An overview of the topic}

The personality of the student, their communicative and educational activities lie at the heart of the modern system of foreign language teaching. This sets special requirements to the process of teaching foreign languages as it should be aimed at implementing the personal, cognitive, and creative process, at developing individuality and subjectivity, the personality of the student. This explains researchers' interest in new technological solutions in the field of language education.

In recent decades, due to intensive informatisation of the foreign language teaching system, the role of computer technologies has increased. The modern system of foreign language teaching is impossible without the use of information and communication technologies (hereafter referred to as ICTs), which ensure enhanced quality of the educational process and formation of key competences of students using new programs, more efficient forms, methods, means, and technologies of teaching" (Bartosh, Galskova \& Kharlamova, 2017, p. 11).

The modern educational process, which is formed in the context of new values and semantic priorities in Language Pedagogy, does not aim to involve learners not in the process of passive mastery of language knowledge, speech skills and abilities, but create the conditions for the conscious and active use of acquired knowledge, speech skills, communicative and special skills by each of the learners. These conditions should enable learners to work together for solving a variety of problems and freely access the necessary information to use it in their speech. It is obvious that such a process can be implemented if the teacher applies interactive and efficient computer-based learning technology (Bartosh, Galskova, Koptelov \& Kharlamova, 2018, p. 71).

The researchers determine that all e-learning tools are based on information and communication technology focused mainly on the transmission of information and the organization of communication with the use of modern computer tools and software based on computer technologies, which can intensify this process significantly. "Using computer-aid learning tools in linguistic education, taking into account their typological characteristics and according to specific educational tasks, allows to implement their specific linguo-didactic functions to the fullest extent" (Bartosh, Galskova, Kharlamova \& Stoyanova, 2019, p.50). Besides effective integration of e-learning technologies into foreign language learning the process helps to improve the quality of language education in general and to expand professional competencies in teacher training (Bartosh, Galskova, Petkova-Kaleva \& Stoyanova, 2019).

A. V. Soboleva highlights in her article the following key provisions of using information technology: 
- The use of multimedia technology in teaching foreign languages is intended to significantly improve the efficiency of teaching, the main purpose of which is to develop the skills of common and professional communication (both directly with native speakers and indirectly through the Internet, the press, etc.);

- Information technology means serve as a tool for education and training the learners, as well as development of their communicative, cognitive, creative abilities and information culture;

- The use of multimedia learning tools makes it possible, in the absence of a natural language environment, to create the conditions that are as close to real speech communication in foreign languages as possible (adapted from Soboleva, 2013).

At the present stage of language education, the following multimedia technologies have become very popular: audio technologies, video technologies, computer technologies, and Internet technologies. The scope of their use in school education is versatile.

Multimedia are computer tools that present the information in various forms (text, audio, graphic, video information) using audio, animated computer graphics, and video and provide a tutor with the ability to interactively work with it.

Multimedia and technologies for teaching the foreign language contribute to the formation of necessary competences, and their application in the process of teaching the foreign language increases the efficiency of teacher and learners' activity and provides them with new opportunities for interaction (Bartosh, Galskova \& Kharlamova, 2017, p. 127).

Using multimedia technologies in foreign language lessons, it is possible to solve the key types of linguistic and pedagogical problems, i.e. to use computerbased learning tools for mastering language aspects and forming the skills and abilities in various types of speech activity (Mustafaeva, 2017).

\section{Application of multimedia tools in FLT}

The basic aspects of teaching a foreign language are phonetics, vocabulary, and grammar. When we talk about teaching aspects of language, we understand teaching three aspects of speech activity: phonetic, lexical, and grammatical, which define the language competence of the student. Next, we will consider some examples of using multimedia tools in teaching some aspects of a foreign language. 
Teaching phonetics: it gives the possibility of dubbing, which is important when learning a foreign language outside the language environment. Multimedia resources allow listening to speech in the language being studied, adapting it to level of perception, while adjustment of the audio speed enables breaking up phrases into separate words, simultaneously comparing their pronunciation and spelling. It is also possible to record a word or phrase spoken by a learner for monitoring and self-monitoring purposes.

Grammar teaching: The use of ICT in a grammar lesson is possible when studying almost any topic, for example, when the teacher explains a grammar rule or grammar unit, one can easily demonstrate the formula for its formation and the context of use; when performing lexical-grammatical tasks of interactive character (Bartosh, Galskova, Koptelov \& Kharlamova, 2018, p. 110). With the correct arrangement, proper color design, use of schemes and tables, voice accompaniment, the information will be perceived by the learners more easily and faster, as most of the receptors will be involved. It offers the possibility to come back to the rule again if it is not learned. ICT make the process of monitoring the level of grammatical skill formation through test programs much more interesting and enhance the efficiency of reference support.

Teaching vocabulary: The use of ICT is based on test and game computer programs with visual presentation; extension of passive and active learners' vocabulary (Bovtenko, 2005, p. 97). The relevance of vocabulary teaching is determined by the modern processes of globalization and dialogue of cultures, as well as by decline of language culture. ICT are recommended for use in the study of the most complex topics, in particular phraseology, which is the national-cultural basis of the language (Stoyanova, 2015, pp. 13-16). Learning vocabulary in a non-language environment carries certain difficulties due to the specifics of the language system of the language being studied. Features of the lexical system are manifested when comparing languages (Stoyanova, 2015a, pp. 249-253). Linguodidactic problems of paronymy are often complicated by the phenomenon of cross-language homonymy (Stoyanova, 2019, pp. 479-487).

Thus, the positive use of multimedia in the process of teaching a foreign language includes: visibility, vividness, audio support, self-test, enhanced learning quality and individualization of the learning process.

According to S.A. Voitko, the main fields of applying ICT in lessons are as follows:

1.The use of ready-made multimedia products and computer learning systems.

2.Creation of own multimedia and training programs.

3.Creating own multimedia presentations.

4.Using ICT in out-of-class activities. 
5.Using the Internet resources (Voitko, 2004, p. 9).

\section{iSpring as a professional tool for creating electronic lessons}

Looking at the ready-made multimedia products we can provide some more details on one of them, i.e. iSpring, which is a professional tool for creating electronic versions of lessons. With its help, one can create and publish a training course in several stages:

- Forming a training course based on PowerPoint presentation

- Developing audio and video accompaniment

- Interactive test development

- Creating interactive blocks (Book - one can quickly create their own three-dimensional interactive book, complement it with images, design the cover, and set the page texture. The effect of flipping the pages makes the book particularly realistic. WithCatalogue interactivity, you can create a glossary, a reference book, or a title catalogue. Teachers can add images, audio, and video files. Timeline is an interactivity allowing to visualize the chronology of events. Description of periods and events can be accompanied by images, as well as audio and video materials).

According to Kryuchkova (2017, p. 119-120), the main features of using iSpring Suite include: variability of forms of teaching; efficient, dynamic, and flexible presentation of material and its adaptation to the level of learners; creative nature of lessons; active involvement of learners in the learning process.

The organization of the learning process using iSpring software allows boosting the motivation for learning a foreign language, developing the ability and readiness for independent learning a foreign language. The forms and types of interaction between teacher and learners create a favorable atmosphere in the lesson and the prerequisites for success.

The application of software enables the teacher to avoid addressing the programmers for creating an electronic manual for a certain training package, which is designed for a specific profile or stage of language teaching and implements the ideas of differentiated management of learning activities in order to obtain and apply relevant knowledge in the form of traditional classroom work, as well as in the mode of remote access to information resources and autonomous work with the computer.

The use of iSpring enables one to implement a fundamentally new approach to foreign language teaching and create a genuine language environment, promoting the natural need to communicate in a foreign language. 
Integration of iSpring into full-time learning as a means for increasing the efficiency of the educational process helps select the learning content; introduce and integrate the selected content into the learning process; control the level of learning at various stages and the variability of the organizational forms of learning.

iSpring is a digital lesson builder, whose content the teacher creates independently, focusing on the program, content and individual characteristics of students.

\section{Conclusion}

The integration of multimedia technologies in the learning process as a means for increasing the educational process efficiency contributes to improving the quality of knowledge, formation and development of communicative competence and motivation to learn a foreign language, creation of favorable conditions for better understanding between teacher and students, their cooperation in the learning process, and effective mastering of the educational material.

It has been proved that using ICT in the educational process, it is possible to solve a number of didactic tasks in a foreign language lesson more effectively, such as:

a) develop reading skills and skills directly using the network's materials of varying degrees of complexity;

b) improve the ability of listening on the basis of authentic sound texts of a network the Internet, are also respectively prepared by the teacher;

c) improve the skills of monological and dialogical utterance based on the problem discussion presented by the teacher or someone from the students, materials of the network;

d) improve writing skills, individually or in writing, making responses to partners, participating in the preparation of abstracts, essays, and other epistolary products of joint activities of partners;

e) supplement learner's vocabulary, both active and passive, with the vocabulary of a modern foreign language that reflects a certain stage in the development of the culture of the people, the social and political structure of society;

f) resort to background knowledge which is culture bound and includes also aspects, such as speech etiquette, behavior in the communicative situation, influence of the culture and traditions of the country of the language being studied;

g) form a stable motivation for foreign language activities of students in the classroom on the basis of systematic use of "live" materials, discussion of not 
only questions to the texts of the textbook, but also topical issues of interest to everyone.

\section{Implications for future work}

The study at hand is by no means exhaustive, as it focuses primarily on the theoretical premises of using ICTs and looks at only one program, i.e. iSpring. Future work can focus on the direct application of said product along with studies on its efficiency which are accompanied by data from experiments conducted among learners of foreign language. As a next step, further ICTs can be analysed and then their efficiency compared to the findings related to iSpring.

\section{References:}

Bartosh, D. K. (2011). Modern educational trends of multimedia teaching of foreign languages. Vestnik universiteta. Moscow: GUU, pp. 12-14.

Bartosh, D. K., Galskova, N. D., Koptelov, A. V., \& Kharlamova, M. V. (2018). Technologies of e-learning of foreign languages: State and prospects. Moscow.

Bartosh, D. K., Galskova, N. D., \& Kharlamova, M. V. (2017). Electronic technology in the system of teaching a foreign language: Theory and practice: Textbook. Moscow: MGPU; Kantsler.

Bartosh, D. K., Galskova, N., Kharlamova, M., \& Stoyanova, E. (2019). Typology of e-learning tools for foreign languages learning. Studies in Linguistics, Culture, and FLT, 6, 50-61.

Bartosh, D., Galskova, N., Petkova-Kaleva, St., \& Stoyanova, E. (2019). Path to the profession of a foreign language teacher. Shumen: Konstantin Preslavsky University Press.

Bartosh, D., Stoyanova, E., Galskova, N., \& Petkova-Kaleva, St. (2020). Teaching foreign languages in the context of cognitive and conceptual priorities of modern education. Ezikov svyat. Orbis Linguarum, 18(1), 186-196.

Bovtenko, M. A. (2005). Information and communication technologies in teaching a foreign language: Textbook. Novosibirsk: Publishing House NGTU.

Kryuchkova, O. N. (2017). Using multimedia software at the lessons of the German language (as a second foreign language). Collection: Creation of a virtual intercultural educational space by means of e-learning technologies Collection of articles. M. MGPU, pp. 114-122.

Mustafaeva, N. I. (2017) The use of multimedia technologies in teaching foreign languages. Molodoj uchenyj, 14 (148), 728-730. 
Polat, E. S. (2005). New pedagogical and information technologies in the education system: textbook. Moscow: Publishing center "Academia".

Soboleva, A. V. (2013). The use of multimedia technologies in teaching a foreign language. Pedagogy: Traditions and innovations: Proceedings of the IV International Scientific Conference (Chelyabinsk, December 2013). Chelyabinsk: Dva Komsomoltsa, pp. 119-123.

Stoyanova,E.(2019). Yavleniyeleksicheskoyparonimiikaklingvometodicheskaya problema. Chuzhdoyezikovo obucheniye. Chuzhdoyezikovo obucheniye, 5, 479-487.

Stoyanova, E. (2015). Phraseology is the part of the lingual and cultural competence of foreign students. SocioBrains International Scientific Refereed Online Journal, Issue 7, March 2015, 13-16.

Stoyanova, E. (2015a). Soznatelyoye sopostavleniye leksicheskikh mikrosistem kak printsip natsionalyno-oriyentirovannogo prepodavaniya russkogo yazyka $\mathrm{v}$ bolgarskoy auditorii. Kulytura russkoy rechi $\mathrm{v}$ usloviyakh mnogoyazychiya: materialy II Mezhdunarodnoy nauchno-prakticheskoy konferentsii (Makhachkala, 18-19 maya 2015 g.) Makhachkala: Izdatelystvo DGU, pp.249-253.

Voitko, S. A. (2004). On the use of information and communication technologies at foreign language lessons. Internet-magazine, 2, 8-10 